\title{
Produksi Telur Ayam Persilangan Merawang dengan Arab
}

\author{
Egg Production of Merawng and Arab Chicken Crossing \\ N. Widayanti ${ }^{1}$, S. Darwati ${ }^{1}, \&$ R. Afnan ${ }^{1}$ \\ ${ }^{1}$ Departemen Ilmu Produksi dan Teknologi Peternakan, Fakultas Peternakan, IPB University \\ Jln. Agatis Kampus IPB University Dramaga, Bogor 16680 \\ Email koresponden author: darwatisri63@gmail.com
}

\begin{abstract}
The egg production of local chiken can be increased by crossing of arab and merawang chicken. This study aimed to observed egg production performances of crossing between merawang $\mathrm{x}$ merawangarab (M-MA), merawangarab $x$ merawang (MA-M), merawangarab $x$ merawangarab (MA-MA), arabmerawang $x$ arabmerawang (AMAM), merawangarab $x$ arab (MA-A), and arab $x$ merawangarab (A-MA). Parameters in this study were egg weight, egg shape index, hen day production and feed conversion. The result showed that the egg weight of MA-M chicken was significantly greater $(\mathrm{P}<0.05)$. than M-MA, MA-MA, AM-AM, MA-A, and A-MA chicken. The MA-A egg index was significantly larger $(\mathrm{P}<0.05)$ than other crossing. Hen day production of M-MA chicken was significantly greater $(\mathrm{P}<0.05)$ and feed convertion was significantly efficient $(\mathrm{P}<0.05)$ than other crossing. MA hens had better production than other hens.
\end{abstract}

Keywords : crossing, egg production, local chicken

\begin{abstract}
ABSTRAK
Produksi telur ayam lokal dapat dilakukan melalui persilangan ayam arab dan merawang. Tujuan penelitian ini untuk mengkaji performa produksi telur pada persilangan merawang x merawangarab (M-MA), merawangarab $\mathrm{x}$ merawang (MA-M), merawangarab $\mathrm{x}$ merawangarab (MA-MA), arabmerawang $\mathrm{x}$ arabmerawang (AM-AM), merawangarab $\mathrm{x}$ arab (MA-A), and arab $\mathrm{x}$ merawangarab (A-MA). Peubah yang diamati yaitu bobot telur, indeks telur, produksi telur harian, dan konversi pakan. Uji T digunakan untuk mengetahui perbedaan setiap peubah pada persilangan yang berbeda. Hasil penelitian menunjukkan bahwa bobot telur ayam MA-M lebih besar dibandingkan ayam persilangan lainnya $(\mathrm{P}<0.05)$. Indeks telur A-MA lebih besar dibandingkan ayam persilangan yang lain $(\mathrm{P}<0.05)$. Produksi telur harian dan efisiensi pakan ayam M-MA lebih besar dibandingkan ayam persilangan yang lain $(\mathrm{P}<0.05)$. Performa produksi telur induk betina MA memiliki produksi telur yang lebih baik.
\end{abstract}

Kata kunci : ayam lokal, persilangan, produksi telur

\section{PENDAHULUAN}

Ayam lokal berperanan sebagai sumber produksi daging dan telur untuk meningkatkan kualitas gizi masyarakat, disamping sebagai sumber pendapatan tambahan. Akan tetapi, dalam memproduksi daging dan telur, produktivitas ayam lokal lebih rendah dibandingkan dengan produktivitas ayam ras pedaging maupun petelur. Oleh karena itu, perlu dilakukan perbaikan genetik ayam lokal Indonesia.

Upaya pengembangan ayam lokal dengan tujuan meningkatkan produktivitas perlu ditunjang oleh teknologi yang tepat. Berbagai aspek teknis dapat dilakukan seperti perbaikan mutu genetik dan cara pemeliharaan dari tradisional ke semi intensif dan intensif. Peningkatkan produktivitas ayam lokal dapat dilakukan dengan upaya perbaikan mutu genetik, pakan, budi daya, dan pengendalian penyakit (Nataamijaya 2010).

Ayam arab dan ayam merawang adalah ternak unggas lokal Indonesia. Ayam arab merupakan ayam yang banyak dikembangkan karena memiliki potensi sebagai ayam petelur unggul. Begitu pula dengan ayam merawang yang sangat potensial untuk dikembangkan baik sebagai ayam lokal petelur dan pedaging. Darwati et al. (2017) telah melakukan persilangan ayam merawang dengan arab dan resiprokalnya yang menghasilkan ayam merawang-arab (MA) dan arab-merawang (AM).

$$
\text { Persilangan ayam merawang-arab }
$$


menghasilkan telur tetas dengan bobot $43.423 \pm 4.29 \mathrm{~g}$. Persilangan ayam arab-merawang (AM) menghasilkan bobot telur tetas 52.504 $\pm 3.050 \mathrm{~g}$ (Darwati et al. 2017). Oleh karena itu, penelitian ini dilakukan untuk mengkaji performa produksi telur ayam persilangan ayam merawang $\mathrm{x}$ merawangarab (M-MA), merawangarab $\mathrm{x}$ merawang (MA-M), merawangarab x ayam merawangarab (MA-MA), arabmerawang $\mathrm{x}$ arabmerawang (AM-AM), merawangarab $\mathrm{x}$ arab (MA-A), arab x merawangarab (A-MA). Persilangan antar ayam lokal tipe petelur ini diharapkan dapat menjadi solusi untuk peternak dalam penyediaan telur ayam lokal yang mempunyai mutu genetik yang baik.

Penelitian dilakukan untuk mengkaji performa produksi telur hasil persilangan ayam merawang $\mathrm{x}$ merawangarab (M-MA), merawangarab x merawang (MA$\mathrm{M}$ ), merawangarab $\mathrm{x}$ ayam merawangarab (MA-MA), arabmerawang $\mathrm{x}$ arabmerawang (AM-AM), merawangarab $\mathrm{x}$ arab (MA-A), arab x merawangarab (A-MA).

\section{METODE}

\section{Waktu dan Tempat Penelitian}

Penelitian dilaksanakan di Laboratorium Lapang Pemuliaan dan Genetika Fakultas Peternakan, Institut Pertanian Bogor.

\section{Materi Penelitian}

Bahan yang digunakan pada penelitian adalah ayam persilangan MA-A, A-MA, MA-MA, MA-M, M-MA, dan AM-AM serta pakan ayam untuk ayam ras pedaging fase starter juga dedak padi.

\section{Prosedur Penelitian}

Kandang dipersiapkan terlebih dahulu dan dibersihkan dengan menggunakan sapu lidi sebelum dilakukan persilangan. Lantai kandang diberi kapur, lalu ditabur sekam. Alas kandang berupa sekam dan dilakukan pergantian jika sekam kotor dan basah.

Terdapat 6 persilangan ayam yang dilakukan pada penelitian ini dengan perbandingan jantan dan betina 1:2. Ayam MA-A, A-MA, dan MA-MA memiliki ulangan sebanyak 3 ulangan, serta 1 ulangan untuk MA-M, M-MA, dan AM-AM.

\section{Pakan dan Air Minum}

Pemberian pakan dilakukan pada pagi hari pukul 06.00 WIB dan sore hari pukul 16.00 WIB. Pakan yang diberikan berupa pakan komersil petelur (kandungan protein 17\%) dan dedak padi dengan perbandingan 60:40. Pemberian air minum ad libitum.

\section{Analisis Data}

Analisis secara deskriptif digunakan untuk mengetahui rataan (x), simpangan baku (SD) dan koefisien keragaman. Uji t digunakan untuk mengetahui perbedaan rataan bobot telur, indeks telur, produksi telur (hen-day production), fertilitas, daya tetas, mortalitas embrio, rasio bobot DOC dengan bobot telur tetas, konsumsi, dan konversi pakan.
Rumus uji t adalah sebagai berikut (Walpole 1995).

$$
\mathrm{t}=\frac{(\overline{\mathrm{x}} 1-\overline{\mathrm{x}} 2)-(\mu 1-\mu 2)}{\sqrt{\frac{\mathrm{S}_{12}}{\mathrm{n} 1}}+\sqrt{\frac{\mathrm{S}_{2} 2}{\mathrm{n} 2}}}
$$

Keterangan :

$\mathrm{x} 1$ = rataan sampel 1

$\mathrm{s} 1$ = simpangan baku 1

$\mathrm{x} 2=$ rataan sampel 2

$\mathrm{s} 2$ = simpangan baku 2

$\mu 1=$ rataan populasi 1

$\mathrm{n} 1=$ jumlah sampel 1

$\mu 2=$ rataan populasi 2

$\mathrm{n} 2=$ jumlah sampel 2

\section{Peubah}

Peubah yang diamati adalah sebagai berikut:

1. Bobot telur dalam satuan gram per butir telur

2. Indeks telur $=\frac{\text { Lebar telur }}{\text { Panjang telur }} \times 100 \%$

3. Produksi telur (hen-day production) yaitu persentase jumlah telur yang dihasilkan dari jumlah ayam yang ada $(\%)$

4. Konsumsi pakan (g ekor-1 minggu-1) yaitu selisih jumlah pakan yang diberikan dengan sisa pakan yang tersisa dalam 1 minggu;

5. Konversi pakan, diperoleh dengan membandingkan konsumsi pakan terhadap bobot total produksi telur (g);

\section{HASIL DAN PEMBAHASAN}

\section{Performa Produksi}

Performa produksi telur kombinasi persilangan ayam arab dengan ayam merawang yang diamati pada penelitian adalah bobot telur, indeks telur, dan hen day production. Performa produksi telur, konsumsi dan konversi pakan yang diperoleh ditampilkan pada Tabel 1.

\section{Bobot Telur}

Bobot telur ayam hasil persilangan dari yang terbesar ke terkecil yaitu MA-M, A-MA, MA-MA, M-MA, AM-AM, dan MA-A. Rataan bobot telur hasil persilangan MA-M, MA-MA, MA-A, dan A-MA berbeda nyata $(\mathrm{P}<0.05)$, namun sama pada persilangan M-MA dan AM-AM. Resnawati dan Bintang (2005) menyatakan bahwa bobot telur dipengaruhi oleh ukuran tubuh induk ayam. Induk ayam yang besar menghasilkan telur yang besar. Rataan bobot badan induk betina M yang digunakan dalam penelitian ini yaitu 1866.5 g, MA 1661 g, AM 1586.3 g, dan AM 1285.3 g. Bobot telur ayam MA-M lebih berat dibandingkan A-MA, MAMA, M-MA, AM-AM, dan MA-A karena bobot induk betina $\mathrm{M}$ lebih berat dibandingkan MA, A, dan AM.

Pada Tabel 1 hanya induk dari ayam persilangan MA-A menghasilkan telur dengan bobot paling ringan dibanding ayam persilangan lainnya. Ayam persilangan ini kecuali MA-A memiliki berat telur lebih berat dari ayam merawang yang dilaporkan Nuraini et al. (2016) bahwa berat telur ayam merawang yaitu $40.42 \pm 5.85 \mathrm{~g}$. 
Tabel 1. Performa produksi, konsumsi, dan konversi pakan hasil persilangan ayam arab dengan ayam merawang

\begin{tabular}{|c|c|c|c|c|c|}
\hline \multirow[t]{2}{*}{ Persilangan (n) } & \multicolumn{5}{|c|}{ Rataan $\pm \mathrm{sb}(\mathrm{kk} ; \mathrm{n})$ Performa produksi, konsumsi dan konversi pakan } \\
\hline & Bobot telur (g butir-1) & Indeks telur & Hen day production $(\%)$ & $\begin{array}{c}\text { Konsumsi pakan } \\
\text { (g ekor-1 minggu-1) }\end{array}$ & Konversi pakan \\
\hline M-MA & $42.85 \pm 1.44 \mathrm{~d}$ & $0.77 \pm 0.03 b$ & $80.16 \pm 27.74 a$ & $680.00 \pm 44.30$ & $2.89 \pm 0.39 \mathrm{a}$ \\
\hline \multirow[t]{2}{*}{-8} & $(3.36 ; 100)$ & $(3.76 ; 100)$ & $-34,6$ & $-6,52$ & $-13,32$ \\
\hline & $55.15 \pm 6.19 \mathrm{a}$ & $0.76 \pm 0.02 \mathrm{a}$ & $34.92 \pm 34.35 \mathrm{e}$ & $693.93 \pm 16.50$ & $6.12 \pm 2.78 \mathrm{c}$ \\
\hline MA-M & $(11.22 ; 44)$ & $(3.12 ; 44)$ & $-98,38$ & $-2,38$ & $-5,21$ \\
\hline \multicolumn{6}{|l|}{-2} \\
\hline & $46.55 \pm 3.71 \mathrm{c}$ & $0.78 \pm 0.03 \mathrm{bc}$ & $55.56 \pm 25.81 \mathrm{bd}$ & $682.00 \pm 31.30$ & $5.21 \pm 2.49 \mathrm{bc}$ \\
\hline MA-MA & $(7.97 ; 129)$ & $(4.46 ; 129)$ & $-46,46$ & $-4,6$ & $-47,86$ \\
\hline \multicolumn{6}{|l|}{-8} \\
\hline & $42.78 \pm 2.96 \mathrm{~d}$ & $0.78 \pm 0.02 \mathrm{c}$ & $61.24 \pm 35.16 b c$ & $683.80 \pm 49.80$ & $3.90 \pm 0.91 b$ \\
\hline AM-AM & $(6.91 ; 109)$ & $(2.73 ; 109)$ & $-57,41$ & $-7,29$ & $-23,27$ \\
\hline \multicolumn{6}{|l|}{-2} \\
\hline & $39.20 \pm 2.81 \mathrm{e}$ & $0.80 \pm 0.03 \mathrm{~d}$ & $46.47 \pm 26.06 \mathrm{~d}$ & $697.33 \pm 4.59$ & $5.82 \pm 2.24 b c$ \\
\hline MA-A & $(6.17 ; 145)$ & $(4.25 ; 145)$ & $-56,07$ & $-0,66$ & $-38,39$ \\
\hline \multicolumn{6}{|l|}{-6} \\
\hline & $48.34 \pm 3.86 \mathrm{~b}$ & $0.78 \pm 0.03 \mathrm{c}$ & $57.33 \pm 21.86 \mathrm{c}$ & $700.00 \pm 0.00$ & $3.89 \pm 0.72 b$ \\
\hline A-MA & $(7.98 ; 173)$ & $(4.36 ; 173)$ & $-38,13$ & 0 & $-18,42$ \\
\hline-8 & & & & & \\
\hline
\end{tabular}

Keterangan : $\mathrm{A}=$ Arab; $\mathrm{M}=$ Merawang; $\mathrm{AM}=$ Arab-merawang; $\mathrm{MA}=$ Merawang-arab; $\mathrm{sb}=$ simpangan baku; $\mathrm{n}=\mathrm{jumlah}$ betina; $\mathrm{kk}=$ koefisien keragaman; $\mathrm{n}=$ jumlah sampel; angka yang disertai huruf kecil berbeda pada kolom yang sama menunjukkan berbeda nyata $(\mathrm{P}<0.05)$

\section{Indeks Telur}

Indeks telur yang dihasilkan MA-MA sama dengan M-MA, A-MA, dan AM-AM, namun berbeda nyata $(\mathrm{P}<0.05)$ pada MA-M dan MA-A. Menurut Yumna et al. (2013), bentuk telur dipengaruhi oleh lebar tidaknya diameter isthmus. Semakin lebar diameter isthmus, maka bentuk telur yang dihasilkan cenderung bulat dan apabila diameter isthmus sempit, maka bentuk telur yang dihasilkan cenderung lonjong.

Bentuk telur pada persilangan ayam ini normal dengan indeks telur yaitu 0.76-0.80. Menurut Abidin (2003), bentuk telur tetas normal memiliki indeks telur $70 \%-80 \%$. Indeks telur ayam arab $0.76 \pm 0.04$ (Nataamijaya et al. 2003) dan ayam merawang memiliki indeks telur $0.78 \pm 0.04$ (Nuraini et al. 2016).

\section{Produksi Telur}

Hen day production (produksi telur harian) merupakan persentase produksi telur pada sekelompok ayam setiap hari. Hasil analisis statistik menunjukkan hen day production ayam hasil persilangan tersebut berbeda nyata $(\mathrm{P}<0.05)$ dengan hen day production tertinggi yaitu M-MA $(80.16 \pm 27.74 \%)$ dan terendah pada MA-M $(34.92 \pm 34.35 \%)$. Hal ini disebabkan oleh genetik dari persilangan.

$$
\text { Persilangan M-MA dan MA-M }
$$

memiliki produksi telur yang berbeda nyata $(\mathrm{P}<0.05)$. Persilangan MA-M dengan induk betina merawang memiliki produktivitas yang lebih baik yaitu $34.92 \pm 34 \%$ jika dibandingkan dengan Nuraini et al. (2016) yang melaporkan produktivitas telur ayam merawang pada umur induk betina $1.5-2$ tahun sebesar $11.72 \%$
Produksi telur persilangan MA-MA dan AM-AM yaitu $55.56 \pm 25.81 \%$ dan $61.24 \pm 35.16 \%$. Hasil analisis statistik produksi telur MA-MA dan AM-AM tidak berbeda nyata $(\mathrm{P}>0.05)$. Hal ini disebabkan induk MA dan AM memiliki komposisi gen yang sama yaitu 50\% arab dan 50\% merawang.

Rataan produksi telur MA-A adalah $46.67 \pm 26.06 \%$ dan rataan produksi telur A-MA adalah $57.33 \pm 21.86 \%$ memiliki perbedaan yang nyata $(\mathrm{P}<0.05)$. Produksi telur persilangan MA-A sesuai dengan Suprijatna et al. (2006) yang melaporkan bahwa produksi telur harian ayam arab umur 20-32 minggu sebesar 45.62\%-50.69\%. Rataan hen day production A-MA lebih baik dibandingkan MA-A. Menurut Noor (2004), persilangan dapat meningkatkan proporsi pasangan gen heterosigot. Akibatnya, penampilan keturunannya menjadi lebih baik daripada rataan penampilan tetuanya untuk sifat-sifat tertentu.

Persilangan M-MA memiliki produksi telur tertinggi dibandingkan persilangan lainnya. Hal ini disebabkan perbedaan puncak produksi telur pada individu ayam.

\section{Konsumsi Pakan}

Konsumsi pakan merupakan jumlah pakan yang dikonsumsi oleh ternak untuk mencukupi hidup pokok dan untuk produksi ternak tersebut. Hasil analisis statistik menunjukkan konsumsi pakan pada kombinasi persilangan ayam arab dan merawang memiliki hasil tidak berbeda nyata. Hal ini disebabkan jumlah pemberian pakan dan temperatur lingkungan dalam penelitian mendekati seragam.

Konsumsi pakan ayam pada persilangan ini berkisar $680.00 \pm 44.30-700.00 \pm 0.00 \mathrm{~g}$ ekor $^{-1}$ minggu $^{-1}$. Konsumsi 
pakan sangat bergantung pada ukuran tubuh ternak, sifat genetis (breed), suhu lingkungan, tingkat produksi, perkandangan, tempat pakan per ekor, keadaan air minum, kualitas, dan kuantitas pakan serta penyakit (Suprijatna et al. 2005).

\section{Konversi Pakan}

Konversi pakan merupakan perbandingan antara konsumsi pakan terhadap bobot total produksi telur (g). Konversi pakan persilangan ayam dari yang terbesar ke terkecil yaitu MA-M, MA-A, MA-MA, AM-AM, A-MA, dan M-MA. Rataan konversi pakan pada ayam persilangan ini menunjukkan hasil yang berbeda nyata $(\mathrm{P}<0.05)$ pada M-MA, MA-M, AM-AM, dan A-MA. Namun, tidak berbeda nyata. pada persilangan MA-MA dan MA-A.

Persilangan M-MA memiliki konversi pakan yang lebih efisien dibandingkan ayam persilangan lainnya. Hal ini disebabkan oleh genetik, produksi telur, dan respon indukan terhadap pakan yang diberikan. Indra et al. (2013) menyatakan bahwa konversi pakan dipengaruhi oleh genetik, mutu pakan, jenis kelamin, dan temperatur lingkungan.

\section{KESIMPULAN}

Performa produksi telur dan konversi pakan persilangan M-MA lebih baik dibandingkan persilangan MA-M, MA-MA, AM-AM, MA-A dan A-MA. Ayam induk betina MA memiliki performa produksi telur lebih baik dibandingkan induk betina lainnya.

\section{DAFTAR PUSTAKA}

Abidin Z. 2003. Membuat dan Mengelola Mesin Tetas Semi Modern. Jakarta (ID): Agromedia Pustaka.

Darwati S, Afnan R, Maulana VS. 2017. Growth of merawang chiken with arab chiken crossing and its reciprocal at 1 to 10 weeks of age. International Seminar on Tropical Animal Production. Yogyakarta (ID): Universitas Gajah Mada.

Indra GK, Achmanu, Nurgiartiningsih A. 2013. Performans produksi ayam arab (Gallus turcicus) berdasarkan warna bulu. J. Ternak Tropika 14(1): 8-14.

Nataamijaya AG, Setioko AR, Brahmantyo B, Diwyanto K. 2003. Performans dan karakteristik tiga galur ayam lokal (pelung, arab, dan sentul). hlm. 353-359. Prosiding Seminar Nasional Teknologi Peternakan dan Veteriner, 29-30 September 2003. Bogor (ID): Pusat Penelitian dan Pengembangan Peternakan.

Nataamijaya AG. 2010. Pengembangan potensi ayam lokal untuk menunjang peningkatan kesejahteraan petani. Jurnal Litbang Pertanian 29(4) : 131-13.

Noor RR. 2004. Genetika Ternak. Cetakan ke-3. Jakarta (ID): Penebar Swadaya.

Nuraini, Hidayat Z, Adrial. 2016. Produksi dan karakteristik telur ayam merawang dengan system pemeliharaan secara intensif di Kebun Percobaan Petaling Kepulauan Bangka Belitung. Prosiding Seminar Nasional Inovasi Teknologi Pertanian. Banjarbaru (ID): BPTP Kalsel.

Resnawati H, Bintang IAK. 2005. Produktivitas ayam lokal yang dipelihara secara intensif. Lokakarya Nasional Inovasi Teknologi Pengembangan Ayam Lokal. Bogor (ID): Balai Penelitian Ternak.

Saepudin A. 2015. Performa produksi telur dan reproduksi hasil persilangan ayam lokal dengan ayam ras pedaging [skripsi]. Bogor (ID): Institut Pertanian Bogor.

Suprijatna E, Atmomarsono U, Kartasujana R. 2005. Ilmu Dasar Ternak Unggas. Jakarta (ID) : Penebar Swadaya.

Suprijatna E, Mahfudz LD, Sarengat W. 2006. Performans produksi telur ayam arab akibat pemberian ransum berbeda taraf protein saat pertumbuhan. Seminar Nasional Teknologi Peternakan dan Veteriner. Semarang (ID): Universitas Diponegoro.

Walpole RE. 1995. Pengantar Statistika. Jakarta (ID): Gramedia Pustaka Utama.

Yumna MH, Zakaria A, Nurgiartiningsih VMA. 2013. Kuantitas dan kualitas telur ayam arab (Gallus turcicus) silver dan gold. Jurnal Ilmu-Ilmu Peternakan 23 (2): $19-24$. 